\title{
MINERAL RESOURCE POTENTLAL AND GEOLOGY OF THE WHEELER WILDERNESS STUDY AREA, MINERAL COUNTY, COLORADO
}

\author{
By \\ William H. Raymond and James G. Crock, \\ U.S. Geological Survey \\ and \\ Carl L. Bieniewski, U.S. Bureau of Mines
}

\section{STUDIES RELATED TO WILDERNESS}

Under the provisions of the Wilderness Act (Public Law 88-577, September 3, 1964) and related acts, the U.S. Geological Survey and the U.S. Bureau of Mines have been conducting mineral surveys of wilderness and primitive areas. Areas officially designated as "wilderness," "wild," or "canoe" when the act was passed were incorporated into the National Wilderness Preservation System, and some of them are presently being studied. The act provided that areas under consideration for wilderness designation should be studied for suitability for incorporation into the Wilderness System. The mineral surveys constitute one aspect of the suitability studies. The act directs that the results of such surveys are to be made available to the public and be submitted to the President and the Congress. This report discusses the results of a mineral survey of the Wheeler Wilderness Study Area, Rio Grande National Forest, Mineral County, Colo., which was established as a study area under Public Law 96-560, December 1980.

\section{MINERAL RESOURCE POTENTIAL SUMMARY STATEMENT}

There are no indications of significant mineral deposits within the Wheeler Wilderness Study Area, and no mining claims or permits are known to have existed within it. Low-level anomalous concentrations of gold, uranium, and zinc were found in a few stream-sediment samples and panned concentrates, but the occurrences are randomly distributed, and there is little likelihood that they are related to concealed mineral deposits. A zeolite mineral (phillipsite?), which occurs in very small amounts in altered tuff, does not represent a resource commodity.

The study area is underlain entirely by volcanic rocks of Oligocene age, which have been interpreted to be within a huge volcanic subsidence structure about $25 \mathrm{mi}$ in diameter, La Garita caldera (Steven and Lipman, 1976; Steven and Bieniewski, 1977). The possibility of intrusive rocks beneath parts of the study area is indicated by two magnetic highs (fig. 4) that extend into the adjoining La Garita Wilderness (U.S. Geological Survey, 1972). Despite these somewhat favorable aspects of geology and structure, the area has a low potential for occurrence of metallic mineral deposits.

\section{INTRODUCTION}

\section{Area Description}

The Wheeler Wilderness Study Area, in the San Juan Mountains of Colorado, adjoins La Garita Wilderness on the north and encompasses an area of about 14,000 acres (about $21.8 \mathrm{mi}^{2}$ ). It includes the land formerly designated the Wheeler National Monument, which is near the center of the study area and consists of about one-half square mile containing about 66 acres of deeply dissected tuff.

Access to the study area is by four-wheel-drive road (U.S. Forest Service Road 600) from Colorado State Highway 149 near Wagon Wheel Gap for $14 \mathrm{mi}$ to the edge of the Wheeler Geologic Area (fig. 1). Other access is by foot and pack trails from Saguache Park, Creede, the Phipps Ranch, and from East Bellows Creek. La Garita and Alder Stock Driveways are among the pack trails crossing the study area (fig. 1).

The northern boundary of the study area is La Garita divide, which is also the Mineral-Saguache County line. Other boundaries are not defined by explicit geographic features. The elevations in the area range between 12,881 and about $8,800 \mathrm{ft}$. The major drainage system is West Bellows Creek, which is flanked on the west by Wason Park and on the east by Silver Park.

\section{History}

The "Wheeler geologic formations" were named in honor of Captain George M. Wheeler, who conducted geologic surveys of Colorado between 1873 and 1884 . In 1908 Theodore Roosevelt designated a 300-acre Wheeler National Monument, which was administered by the U.S. Forest Service until 1933, when jurisdiction was transferred to the National Park Service. In 1950, 


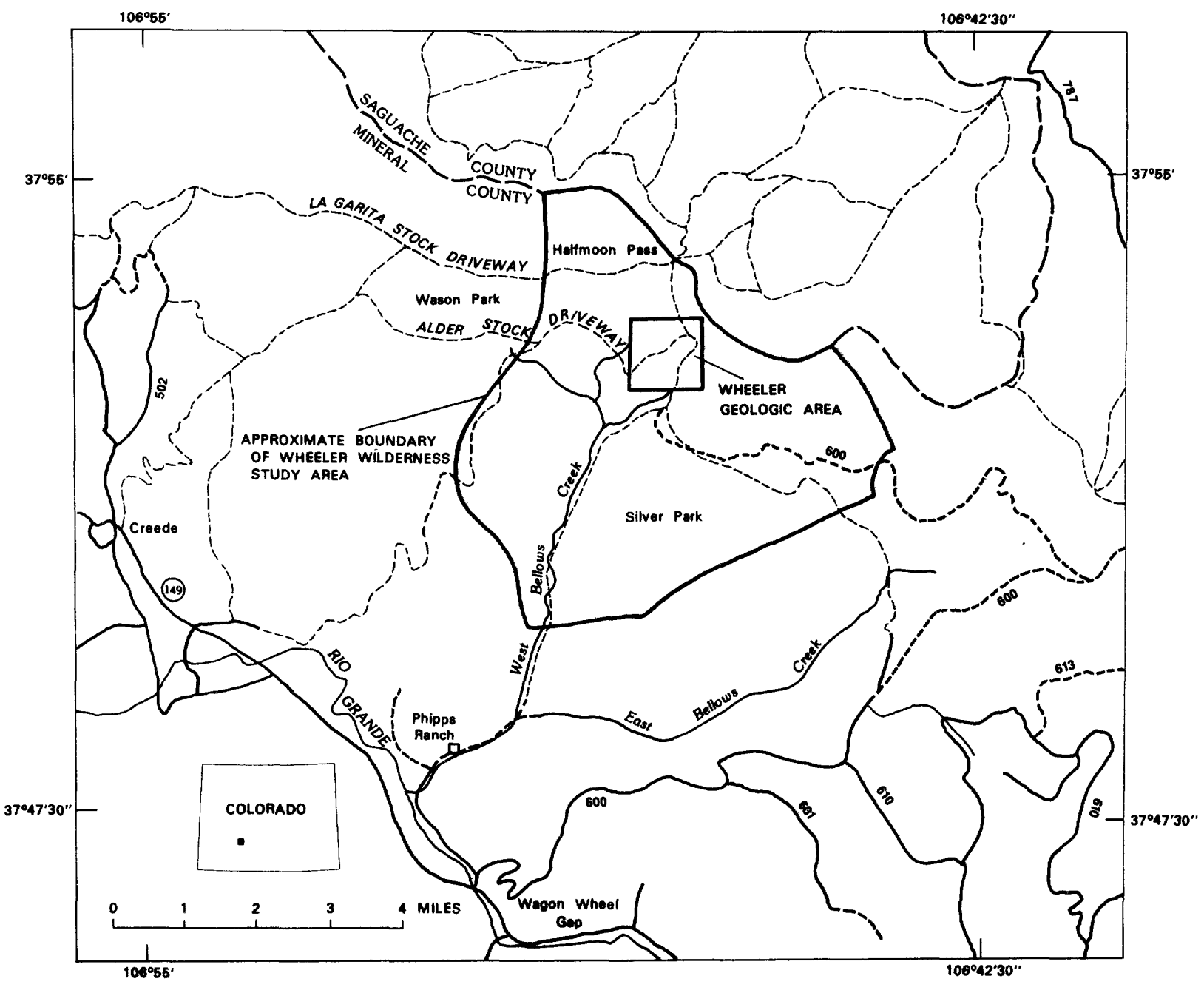

Figure 1.--Index map showing 1ocation of the Wheeler Wilderness Study Area, Mineral County, Colo. 
Congress passed P.L. 652, which abolished the Wheeler National Monument and returned management responsibility to the U.S. Forest Service. In 1962, a 640-acre tract, including the "geologic formations," was withdrawn from mineral prospecting, location, entry, or purchase by Public Land Order 2372; the 640-acre tract was thereafter referred to as the Wheeler Geologic Area. Although the study area has not been designated for wilderness, the Secretaries of Agriculture and Interior have been directed to conduct a comprehensive study of alternatives for future management of the area.

\section{Previous Investigations}

The geology of the study area was mapped by Steven in 1961-1971 (Steven and Bieniewski, 1977) and by Steven and Ratte(1973; see fig. 3, this report). An aeromagnetic survey, which included the study area, was flown in 1968 (U.S. Geological Survey, 1972). Plouff and Pakiser (1972) conducted a gravity study of the San Juan Mountains.

C. L. Bieniewski, U.S. Bureau of Mines, examined the study area briefly in 1971 for location of any mines, prospect workings, and mineralized areas during the field investigation of La Garita Wilderness; none were found.

\section{Present Investigation}

Fieldwork for this study was conducted in July 1982 to evaluate the mineral resource potential of the study area. This work included collecting samples of rocks, stream sediments, and panned concentrates for analysis.

There is no known mining or prospecting activity in the study area, and no prospect pits, claim markers, or other signs of prospecting activity were noticed during fieldwork. A search of records indicated that no mining claims have been recorded in the study area, and no mineral production has been reported as coming from the study area.

\section{GEOLOGY}

The study area is underlain entirely by volcanic rocks, mainly thick ash-flow-tuff deposits of Oligocene age, most of which were deposited within the huge La Garita caldera (see fig. 2; Steven and Lipman, 1976). Eruptions of the Fish Canyon Tuff, the oldest rock exposed in the study area, were responsible for the collapse of La Garita caldera. The Fish Canyon Tuff occurs on the resurgent dome of the caldera in the northern part of the study area.

Most of the rocks of the study area were deposited after the resurgent doming of La Garita caldera and occupy the moat along the northeast wall of the caldera.

Two major faults crossing the area, trending generally west-northwest, may be part of the ringfracture zone of the younger Bachelor caldera, which is nested in the western side of La Garita caldera. The eastern boundary of the Bachelor caldera, in the study area, is concealed.

Wason Park, which occupies the southwest onethird of the study area, is underlain mainly by Wason Park Tuff (fig. 3), which is composed of red, rhyolitic ash-flow tuff containing phenocrysts of tabular feldspar, platy biotite, and sparse augite and characteristic white, tridymitic, collapsed pumice fragments.

Silver Park, which occupies the southeastern one-third of the study area (fig. 3 ), is underlain mainly by quartz latite and rhyolite lavas and breccias.

The northern one-third of the study area is underlain mainly by Fish Canyon Tuff, Rat Creek Tuff, and Nelson Mountain Tuff (fig. 3). The surficial geology includes substantial areas of glacial drift and landslide debris.

The canyon of West Bellows Creek cuts through Wason Park Tuff, through the quartz latite and rhyolite that underlie Silver Park, and into various underlying units of volcanic rock not extensively exposed in the main part of the study area.

The former Wheeler National Monument consisted of about one-half square mile containing about 66 acres of deeply dissected outcrops of white, gray, and buff Rat Creek Tuff. This picturesque area of badlands is modified by small areas of large slump blocks that, in conjunction with extremely steep slopes and spires, make the area almost impossible to traverse.

\section{GEOPHYSICAL INTERPRETATION}

According to Eaton (1977), the Bouguer gravity map of Plouff and Pakiser (1972) is not adequate for mineral assessment because too few gravity stations were established in the area. An aeromagnetic map (U.S. Geological Survey, 1972), however, was prepared from a survey flown in 1968 at a barometric elevation of $14,500 \mathrm{ft}$ and a flight-line spacing of $1 \mathrm{mi}$; it is sufficiently detailed to aid in assessing the mineral potential of the study area.

Contoured aeromagnetic data for most of the Wheeler Wilderness Study Area and part of the adjoining La Garita Wilderness are shown in figure 4. A broad magnetic anomaly in La Garita Wilderness is surmounted by two smaller highs that are about 650 gammas higher than the peak of the larger anomaly. One of the highs trends northeast across the Wheeler Geologic Area, and another trends northwest along the ridge in the northwest corner of the Wheeler Wilderness Study Area. The local, northeast-trending positive anomaly that crosses the Wheeler Geologic Area is believed to be related to a subsurface body the top of which is calculated to be about $1,000 \mathrm{ft}$ or more below the surface. The elongate, northwest-trending high, which follows the Saguache-Mineral County line, is interpreted as an expression of the topographic ridge carved frum the normally polarized, intercaldera La Garita Tuff Member of the Fish Canyon Tuff.

No evidence was found to suggest that either magnetic anomaly has mineralization associated with it.

\section{GEOCHEMISTRY}

\section{Zinc}

Anomalous amounts of zinc (110-510 ppm) are present over a wide area in the drainage of West Bellows Creek. Four panned concentrates containing 400-510 ppm zinc suggest no coherent pattern that might indicate concealed ore deposits. Streamsediment samples taken at the same sites contain significantly less zinc (see fig. 5 for sample localities). 


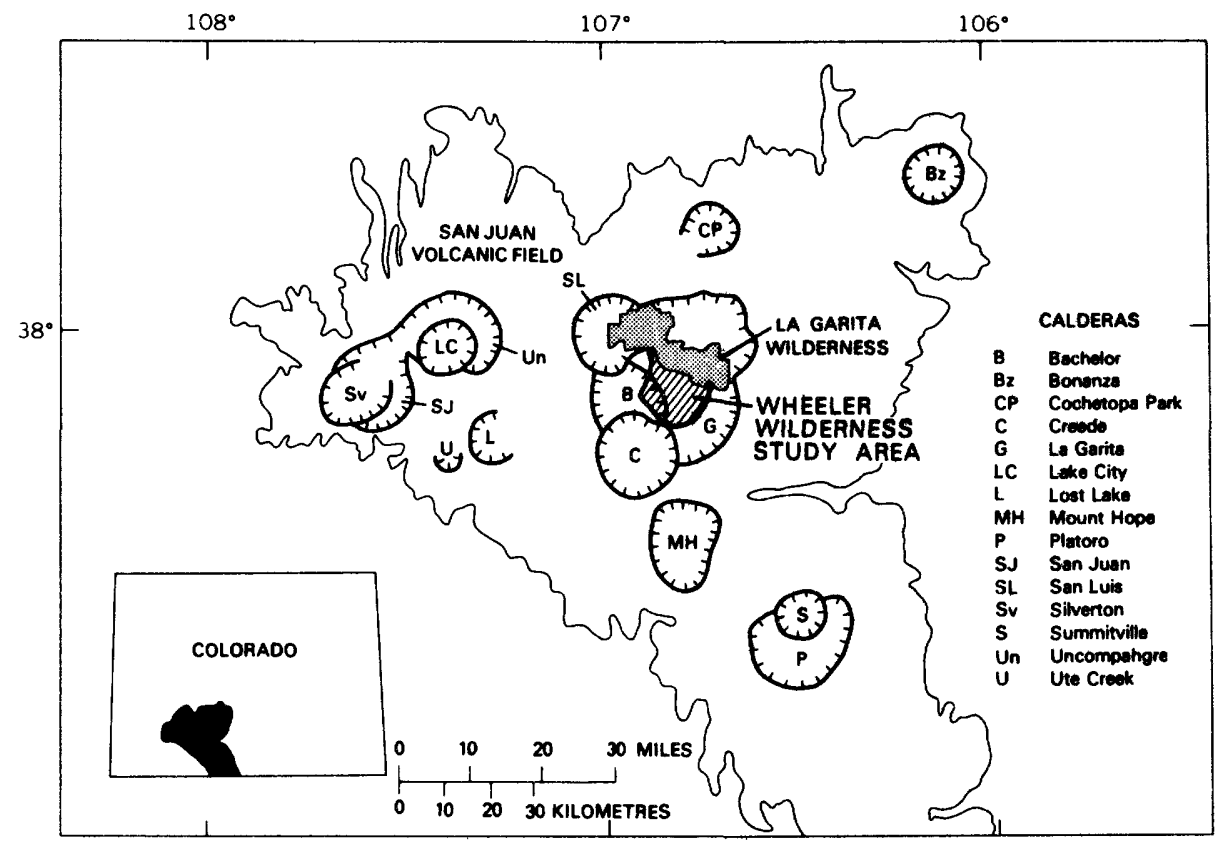

Figure 2.--Map showing location of the Wheeler Wilderness Study Area and La Garita Wilderness in relation to calderas in the San Juan volcanic field, southwestern Colorado (from Steven and Bieniewski, 1977, p. 3). 


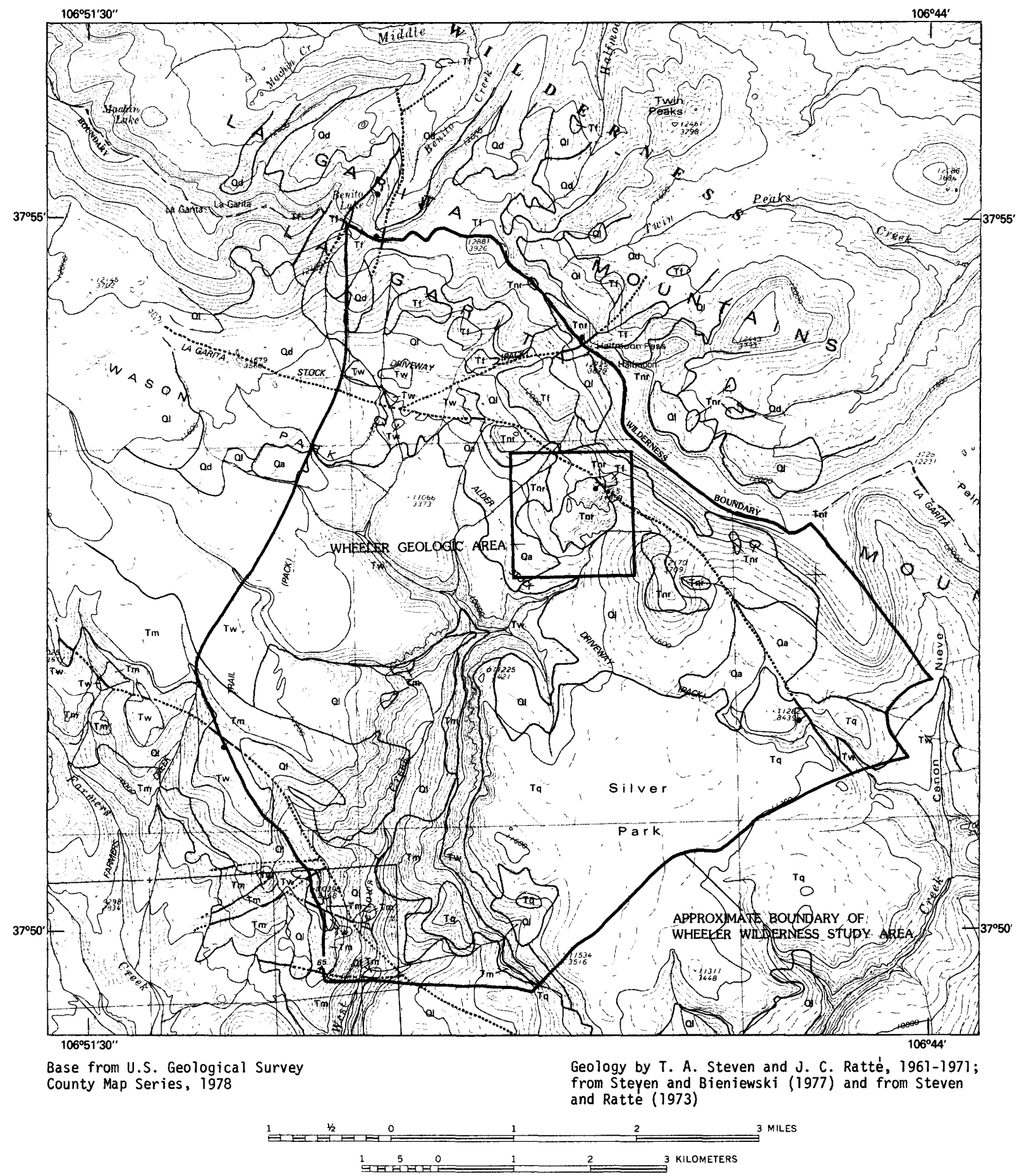

Figure 3.--Geologic map of the Wheeler Wilderness Study Area, Mineral County, Colo. 
EXPLANATION

CORRELATION OF MAP UNITS

\begin{tabular}{|c|c|c|c|c|}
\hline Qa & Q1 & Qd & \multirow{5}{*}{01 igocene } & QUATERNARY \\
\hline & $\operatorname{Tn} r$ & \multirow{3}{*}{$\mathrm{Tq}$} & & \multirow{4}{*}{ TERTIARY } \\
\hline & Tw & & & \\
\hline & $\mathrm{Tm}$ & & & \\
\hline & $\operatorname{Tf}$ & & & \\
\hline
\end{tabular}

LIST OF MAP UNITS

Qa ALLUVIUM AND TERRACE GRAVELS (QUATERNARY)

Q1 LANDSLIDE DEBRIS (QUATERNARY)

Qd GLACIAL DRIFT (QUATERNARY)

Tnr NELSON MOUNTAIN TUFF AND RAT CREEK TUFF, UNDIVIDED (OLIGOCENE)

Tq QUARTZ LATITE AND RHYOLITE BRECCIAS (OLIGOCENE)

Tw WASON PARK TUFF (OLIGOCENE)

Tm MAMMOTH MOUNTAIN TUFF (OLIGOCENE)

Tf FISH CANYON TUFF (OLIGOCENE)

CONTACT

FAULT--Bar and ball on downthrown side. Dashed where inferred; dotted where concealed

Figure 3.--Cont inued. 


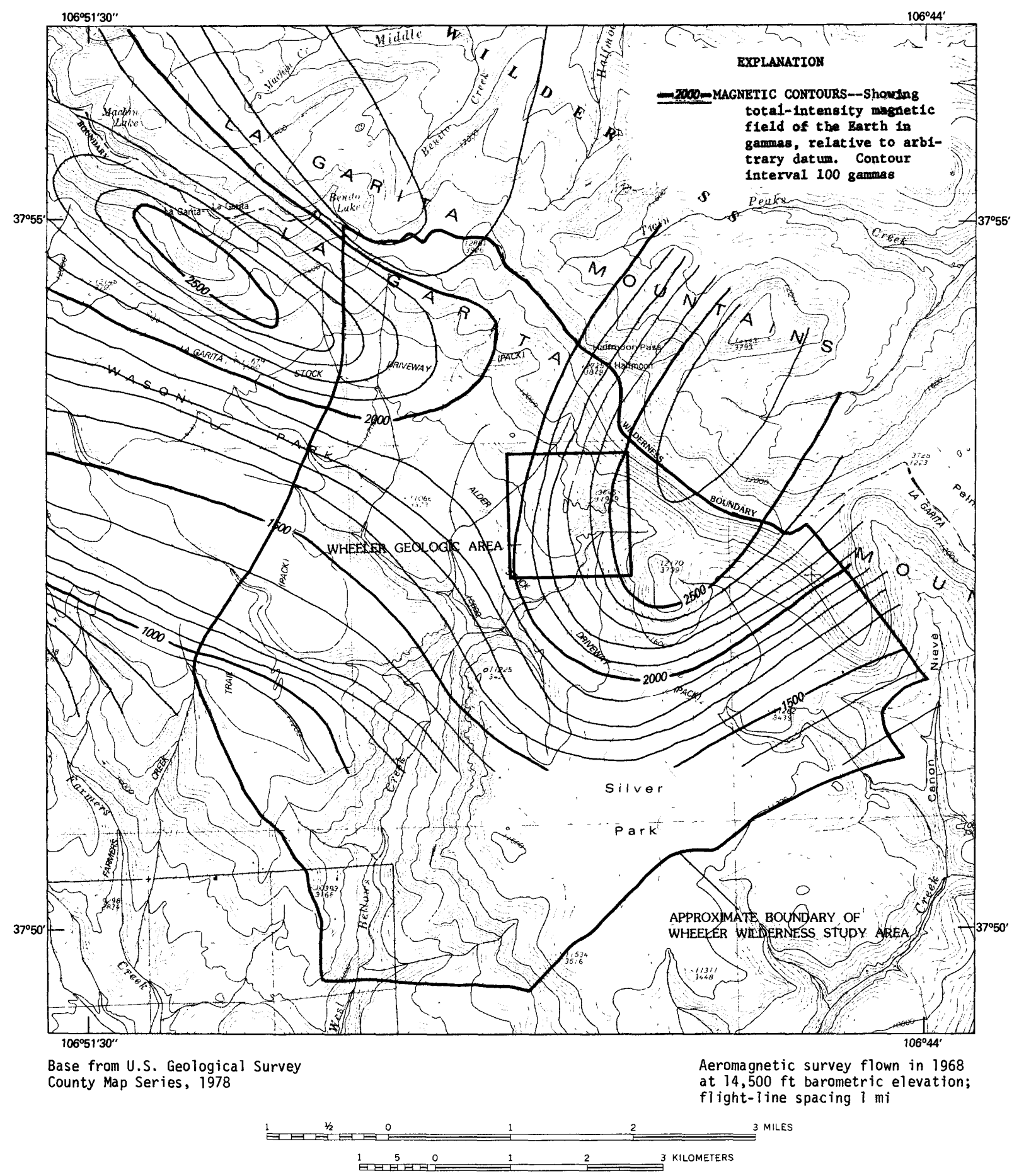

Figure 4.--Aeromagnetic map of the Wheeler Wilderness Study Area, Mineral County, Colo. 


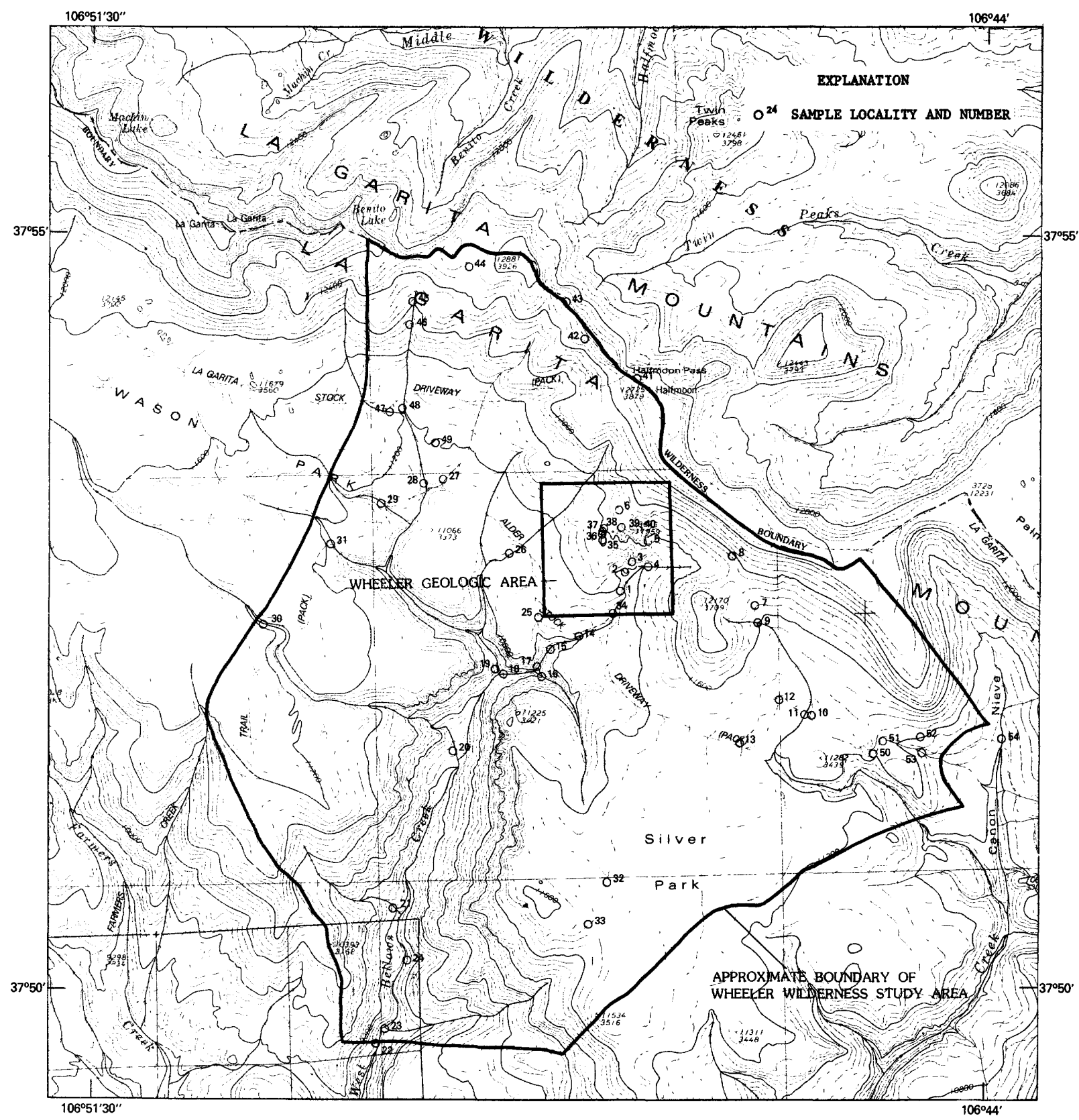

Base from U.S. Geological Survey County Map Series, 1978

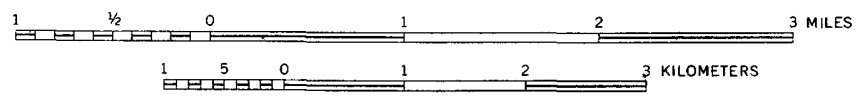

Figure 5.--Map showing sample localities, Wheeler Wilderness Study Area, Mineral County, Colo. 
According to T. A. Steven (oral commun., 1982), much of the zinc in the stream sediments is in volcanic magnetite. This was confirmed by analyses of magnetic concentrates for six samples containing anomalous concentrations of zinc. The results are compared in table 1 for zinc contents of raw stream sediments, panned concentrates, and magnetic concentrates. Samples containing more than $100 \mathrm{ppm}$ zinc are also listed in table 2. Inasmuch as the zinc is lodged in volcanic magnetite, there is little resource potential for zinc in the study area. Figure 6 shows sample localities where anomalous amounts of metals were detected.

\section{Uranium}

Scintillometer readings taken in the study area range between 85 and 110 counts per second. Readings taken with the same instrument in other areas of Colorado are generally 40-60 counts per second. No areas of spuriously high radiation were detected by the scintillometer; but, rather, a consistently high background is characteristic.

However, analytical data (ICP, induction-coupled plasma) show that in five samples uranium is slightly greater than the lower detection limit of the method. The range of uranium content is relatively high (as much as $50 \mathrm{ppm}$ ) and probably varies between 30 and $50 \mathrm{ppm}$.

Previous work done in the region by others (R. A. Zielinski, oral commun., 1982) suggests that uranium in volcanic glass in the rocks is commonly about 10-20 ppm. There is no evidence to suggest accumulations of uranium in concentrations greater than $50 \mathrm{ppm}$.

The visual distribution (fig. 6) of localities for the five samples mentioned above shows no coherent anomaly suggesting significant uranium accumulation.

The five anomalous samples and five other randomly selected samples were analyzed by delayed neutron activation; the results shown in table 3 indicate that amounts of uranium are less than reported under the ICP method. As a result, future ICP results $w i l l$ be reported using a higher limit of detection (see Crock and others, 1983).

\section{Gold}

Only one sample (stream-sediment sample 23) is shown to contain gold in concentrations greater than the detection limit of $4 \mathrm{ppm}$, ICP method (table 2). That amount is only slightly above the detection limit and may not be reliable.

The absence of detectable gold in panned concentrates from the study area and, indeed, of any other detectable gold in samples from the study area, coupled with the absence of detectable silver in samples from the study area, suggests that the reported gold content is spurious and that concealed precious-metals deposits in the study area are unlikely.

\section{$\operatorname{Tin}$}

Traces of tin appear in six panned concentrates. Values range from 6-14 ppm (table 2).

The amounts of tin contained in the abovementioned six samples are too small to be considered significant. Inasmuch as the six tin-bearing samples are panned concentrates, the tin mineral occurs as fine detrital grains or is incorporated in another heavy mineral such as magnetite. No detectable amounts of tin $04 \mathrm{ppm}$ ) were found in stream-sediment samples taken at the same sample localities as the panned concentrates.

\section{Zeolites}

The rocks of the Rat Creek Tuff, which form the spectacular badlands outcrops in the Wheeler National Monument area, were studied by X-ray diffraction techniques for possible zeolite minerals reported by Steven and Bieniewski $(1977$, p. 11). The zeolite mineral phillipsite has been tentatively identified in 4 of the 14 samples studied. Rough estimates, by X-ray diffraction, indicated a phillipsite content of 1-10 percent, much too low to be of commercial interest.

The major minerals in the Rat Creek Tuff samples collected for this study are volcanic glass, albite, quartz, unidentified clay minerals, and phillipsite.

\section{ASSESSMENT OF MINERAL RESOURCE POTENTIAL}

The exposed rocks of the study area are entirely of volcanic origin, mainly ash-flow debris filling the subsiding La Garita caldera. The eastern part of the Bachelor caldera, nested within the western part of La Garita caldera, is included in the western part of the study area. The inferred ring-fracture zone of the eastern boundary of the Bachelor caldera may be expressed by west-northwest-trending faults in the study area. Possible veins related to that faulting could constitute hosts for mineral deposits, but evidence of such veins has not been found.

There are no indications of significant mineral deposits within the Wheeler Wilderness Study Area, and no mining claims or permits are known to have existed within it. Low-level anomalous concentrations of gold, uranium, and zinc were found in a few streamsediment samples and panned concentrates, but the occurrences are randomly distributed, and there is little likelihood that they are related to concealed mineral deposits. A zeolite mineral (phillipsite?), which occurs in very small amounts in altered tuff, does not represent a resource commodity.

\section{REFERENCES CTTED}

Crock, J. G., Raymond, W. H., and Lichte, F. E., 1983, Major, minor, and trace elements in samples from the Wheeler Wilderness Study Area, Colorado, as determined by inductively coupled argon plasma atomic emission spectrometry: U.S. Geological Survey Open-File Report 83-405, 24 p.

Eaton, G. P., 1977, Geophysical interpretation, in Steven, T. A., and Bieniewski, C. L., Mineral resources of the La Garita Wilderness, San Juan Mountains, southwestern Colorado: Geological Survey Bulletin 1420, p. 37-40.

Plouff, Donald, and Pakiser, L. C., 1972, Gravity study of the San Juan Mountains, Colorado, in Geological Survey research 1972: U.S. Geological Survey Professional Paper 800-B, p. B183-B190. 


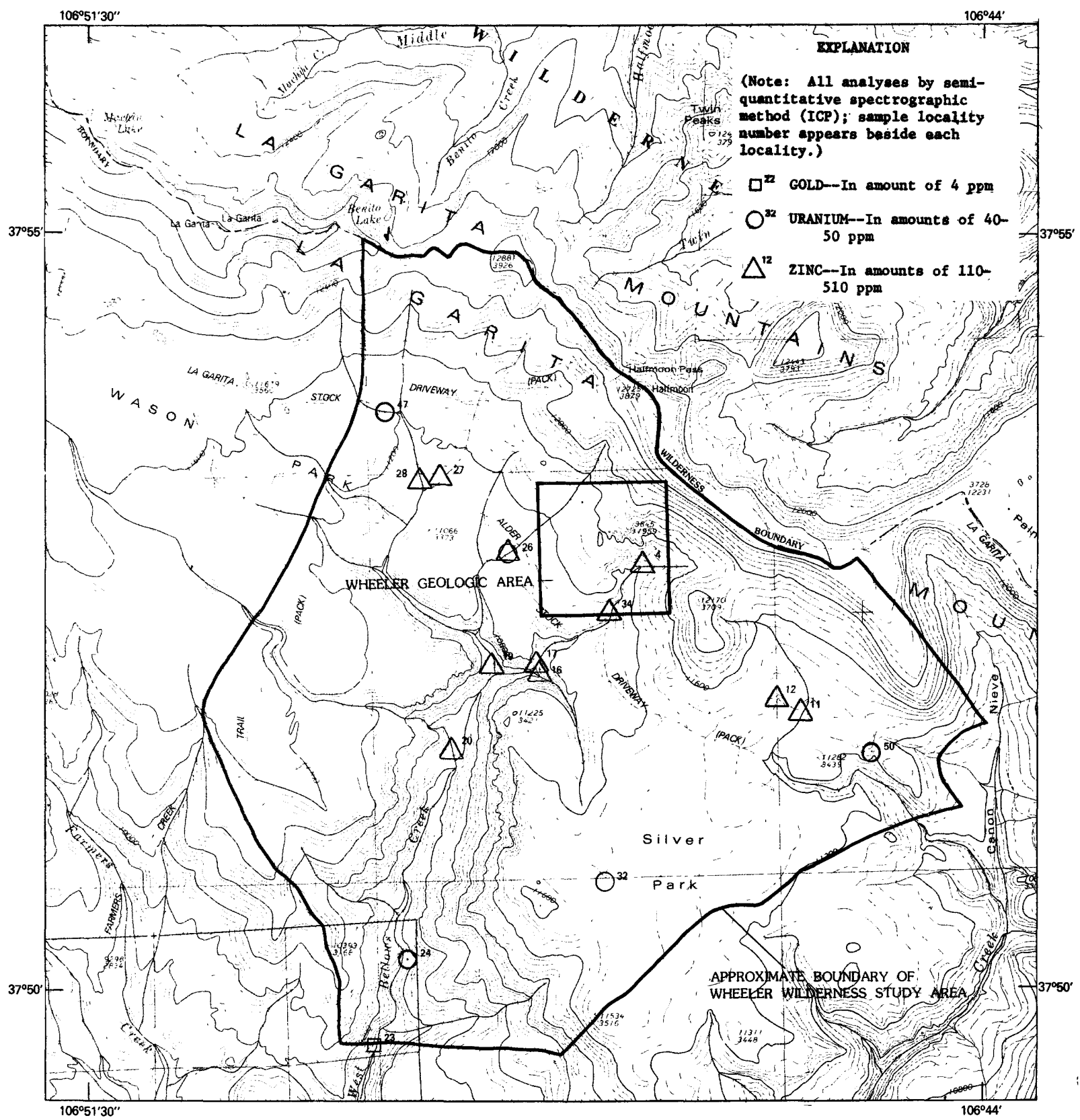

Base from U.S. Geological Survey County Map Series, 1978

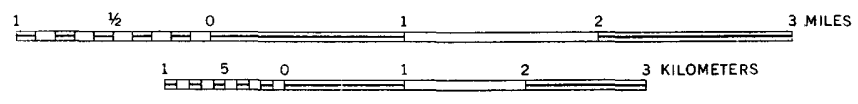

Figure 6.--Map showing localities of chemically anomalous samples, Wheeler Wilderness Study Area, Mineral County, Colo. 
Table 1.--Comparison of zinc contents of streamsediment, panned-concentrate, and magneticconcentrate samples, Wheeler Widerness Study Area

[Results in parts per million. Analyses by J. G. Crock. ICP, induction-coupled plasma; AAS, atomicabsorption spectroscopy]

\begin{tabular}{cccc}
\hline $\begin{array}{c}\text { Sample } \\
\text { No. }\end{array}$ & $\begin{array}{c}\text { Zinc in } \\
\text { stream } \\
\text { sediment } \\
\text { (ICP) }\end{array}$ & $\begin{array}{c}\text { Zinc in } \\
\text { panned } \\
\text { concentrate } \\
\text { (ICP) }\end{array}$ & $\begin{array}{c}\text { Zinc in } \\
\text { magnetic } \\
\text { concentrate } \\
\text { (AAS) }\end{array}$ \\
\hline 4 & 88 & 280 & 1070 \\
12 & 26 & 510 & 1330 \\
17 & 73 & 500 & 1110 \\
19 & 47 & 400 & 620 \\
20 & 36 & 500 & 470 \\
27 & 47 & 320 & 980 \\
\hline
\end{tabular}

Table 3.--Uranium analyses by delayed neutron activation (DNA) compared to inductioncoupled-plasma (ICP) analyses of the same samples in parts per miltion

[ICP analyses by J. G. Crock; DNA analyses by Bruce Vaughn]

\begin{tabular}{|c|c|c|c|}
\hline $\begin{array}{c}\text { Sample } \\
\text { No. }\end{array}$ & Uranium (ICP) & Uranium & $\begin{array}{l}\text { (DNA) } \\
T h^{2}\end{array}$ \\
\hline$W-22$ & $<40$ & 5 & 14 \\
\hline$W-24$ & 40 & 15 & $<6$ \\
\hline$W-26 A$ & 40 & 4 & 10 \\
\hline$W-29$ & $<40$ & 5 & 13 \\
\hline$W-30$ & $<40$ & 5 & 12 \\
\hline$W-32$ & 40 & 2 & 11 \\
\hline$W-43$ & $<40$ & 5 & 14 \\
\hline$W-44$ & $<40$ & 4 & 12 \\
\hline$W-47$ & 50 & 5 & 15 \\
\hline$W-51$ & 50 & 3 & 7 \\
\hline
\end{tabular}

1 Detection limit 0.5 ppr.

${ }^{2}$ Detection limit is a function of U/Th.

Table 2.--Table showing samples containing anomalous zinc, uranium, gold, and $t i n$, Wheeler Wilderness Study Area

[AII samples analyzed by induction-coupled-plasma spectrographic analysis by J. G. Crock. Sample types: SS, stream sediment; $P C$, panned concentrate]

$\begin{array}{ccc}\text { Sample } & \text { Parts } \\ \text { No. } & \text { Type } & \text { per } \\ & & \text { milli }\end{array}$

\begin{tabular}{|c|c|c|}
\hline \multicolumn{3}{|c|}{ Zinc $^{1}$} \\
\hline $\begin{array}{r}4 B \\
12 B \\
16 B \\
17 B \\
19 B \\
20 B \\
26 B \\
27 B \\
28 B \\
11 \\
34\end{array}$ & $\begin{array}{l}P C \\
P C \\
P C \\
P C \\
P C \\
P C \\
P C \\
P C \\
P C \\
S S \\
S S\end{array}$ & $\begin{array}{l}280 \\
510 \\
110 \\
500 \\
400 \\
500 \\
140 \\
320 \\
230 \\
200 \\
150\end{array}$ \\
\hline \multicolumn{3}{|c|}{ Uranium? } \\
\hline $\begin{array}{l}24 \\
26 \mathrm{~A} \\
32 \\
47 \\
51\end{array}$ & $\begin{array}{l}\text { SS } \\
\text { SS } \\
\text { SS } \\
\text { SS } \\
\text { SS }\end{array}$ & $\begin{array}{l}40 \\
40 \\
40 \\
50 \\
50\end{array}$ \\
\hline \multicolumn{3}{|c|}{ Gold 3} \\
\hline 23 & SS & 4 \\
\hline \multicolumn{3}{|c|}{$\operatorname{Tin}^{4}$} \\
\hline $\begin{array}{l}12 B \\
17 B \\
19 B \\
20 B \\
27 B \\
28 B\end{array}$ & $\begin{array}{l}P C \\
P C \\
P C \\
P C \\
P C \\
P C\end{array}$ & $\begin{array}{r}10 \\
8 \\
12 \\
14 \\
9 \\
6\end{array}$ \\
\hline 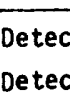 & & $\begin{array}{l}4 \mathrm{ppm} \\
4 \mathrm{ppm}\end{array}$ \\
\hline
\end{tabular}


Steven, T. A., and Bieniewski, C. L., 1977, Mineral resources of the La Garita Wilderness, San Juan Mountains, southwestern Colorado, with a section on Geophysical interpretation, by G. P. Eaton: U.S. Geological Survey Bulletin 1420, $65 \mathrm{p}$.

Steven, T. A., and Lipman, P. W., 1976, Calderas of the San Juan volcanic field, southwestern Colorado: U.S. Geological Survey Professional Paper 958, 35 p.

Steven, T. A., and Ratte, J. C., 1973, Geologic map of the Creede quadrangle, Mineral and Saguache Counties, Colorado: U.S. Geological Survey
Geologic Quadrangle Map GQ-1053, scale $1: 62,500$.

U.S. Geological Survey, 1972 [1973], Aeromagnetic map of the Ridgway-Pagosa Springs area, southwestern Colorado: U.S. Geological Survey Geophysical Investigations Map GP-840, scale $1: 250,000$. 